\title{
MODEL AUTHENTIC LEARNING BAGI PROGRAM KEJURUTERAAN POLITEKNIK \\ MALAYSIA: APLIKASI INTERPRETIVE STRUCTURAL MODELLING
}

\section{(AN AUTHENTIC LEARNING MODEL FOR ENGINEERING PROGRAMMES IN MALAYSIAN POLYTECHNICS: APPLICATION OF INTERPRETIVE STRUCTURAL MODELLING APPLICATION)}

\author{
${ }^{1}$ Mohd Norulhisham Abd Rashid, ${ }^{2}$ Firdaus Mohamad Hamzah, \\ ${ }^{3}$ Mohd Nizam Ab Rahman \& ${ }^{4}$ Mohamad Sattar Rasul \\ ${ }^{1,2,3}$ Fakulti Kejuruteraan \& Alam Bina \\ ${ }^{4}$ Fakulti Pendidikan \\ Universiti Kebangsaan Malaysia, Malaysia
}

${ }^{1}$ Corresponding author: mohdnorulhisham@gmail.com

\begin{abstract}
ABSTRAK
Tujuan - Kajian ini dijalankan untuk membangunkan sebuah model pengajaran berbentuk authentic learning bagi program kejuruteraan di Politeknik Malaysia. Model ini dinamakan sebagai MPAL (Malaysian Polytechnics Authentic Learning). Model MPAL boleh digunakan sebagai garis panduan kepada para pensyarah Politeknik Malaysia dalam melaksanakan aktiviti pengajaran secara authentic learning.
\end{abstract}

Metodologi - Aplikasi Interpretive Structural Modelling (ISM) digunakan dalam pembangunan model MPAL. Pembangunan model ini berdasarkan kepada pandangan serta keputusan bersepadu yang dibuat oleh panel pakar. Seramai tujuh orang panel pakar yang dilantik mewakili Politeknik, Jabatan Pengajian Politeknik dan wakil industri. Terdapat enam langkah utama dalam pembangunan model MPAL bermula dengan mengenal pasti elemen-elemen authentic learning yang berkaitan. Langkah kedua menentukan context dan 
relation dalam aplikasi ISM. Langkah ketiga membangunkan Structural Self-Interaction Matrix (SSIM). Langkah keempat menjana model MPAL dengan aplikasi ISM. Langkah kelima menilai model MPAL yang dihasilkan. Akhirnya, model lengkap MPAL dipersembahkan setelah melalui proses penilaian.

Dapatan - Sebanyak 13 elemen utama dikenalpasti oleh panel pakar bagi perlaksanaan pengajaran secara authentic learning. Setelah penilaian dilakukan oleh panel pakar, model MPAL yang dibangunkan boleh dibahagikan kepada tiga fasa utama yang boleh dilaksanakan dalam pendekatan pengajaran secara authentic learning iaitu FASA 1 (Fasa Permulaan), FASA 2 (Fasa Perlaksanaan) dan FASA 3 (Fasa Penilaian). Terdapat empat elemen dalam FASA 1, tujuh elemen dalam FASA 2 dan dua elemen dalam FASA 3. Pembangunan model MPAL ini bermula daripada kolaborasi antara politeknik, industri dan masyarakat setempat. Model ini berakhir dengan menggalakkan refleksi daripada pelajar serta penilaian kepada pelajar juga perlu dilakukan secara authentic assessment.

Kepentingan - Model MPAL yang dibangunkan boleh menjadi rujukan dan panduan kepada semua pensyarah khususnya bagi Jabatan Kejuruteraan Politeknik Malaysia dalam melaksanakan proses pengajaran dengan lebih berkesan. Di samping itu, model MPAL ini dapat memberi gambaran yang jelas berkenaan dengan keutamaan yang perlu dititikberatkan oleh setiap pensyarah dalam menjalankan aktiviti pengajaran secara lebih bermakna.

Kata kunci: Authentic learning, Interpretive Structural Modelling (ISM), Model Malaysian Polytechnics Authentic Learning (MPAL), Politeknik Malaysia.

\section{ABSTRACT}

Purpose - This study was aimed at developing an authentic learning model for engineering programmes in Malaysian Polytechnics. The model proposed is the MPAL (Malaysian Polytechnics Authentic Learning). 
Design - Interpretive Structural Modelling (ISM) was used in the development of the MPAL model. The model development was based on the integrated views and decision making provided by a panel of seven experts. There were six steps in the development of the MPAL model: identifying the relevant elements of authentic learning, determining the context and relations in the ISM application, developing the Structural Self-Interaction Matrix (SSIM), generating the MPAL model using the ISM application, and evaluating the $M P A L$ model that was produced.

Findings - 13 key elements were identified in the implementation of the authentic learning approach. After the evaluation by the panel of experts, the resultant MPAL model showed that there were three main phases in the implementation of an authentic learning approach, namely PHASE 1 (Initial Phase), PHASE 2 (Implementation Phase) and PHASE 3 (Evaluation Phase). There were four elements in PHASE 1, seven elements in PHASE 2 and two elements in PHASE 3. This model helped to encourage student reflections and enabled authentic assessments of student performance.

Significance - The development of the MPAL model was a collaborative effort between polytechnics, industry and local communities. The MPAL model is a useful reference, especially for Engineering Departments in Malaysian Polytechnics as it provide guidelines in carrying out the process of teaching more efficiently. The model could provide a clear picture regarding the priorities to be considered by each lecturer in their individual attempts to conduct more meaningful teaching activities.

Keywords - Authentic learning, Interpretive Structural Modelling (ISM), Malaysian Polytechnics Authentic Learning Model (MPAL), Malaysian Polytechnics.

\section{PENGENALAN}

Kejayaan dalam pendidikan kejuruteraan dilihat mampu membangunkan sesebuah negara melalui penghasilan jurutera dan modal insan teknikal yang berkualiti. Hal ini kerana, pendidikan 
kejuruteraan merupakan bidang yang berfokuskan kepada kompetensi dan berdaya maju serta mampu menjanjikan pendapatan tinggi kepada negara. Dalam konteks negara Malaysia, cabaran ke-6 dalam Wawasan 2020 jelas mempamerkan usaha kerajaan dalam membina negara yang berpaksikan kepada bidang kejuruteraan dan teknologi (Hanipah, 2010).

Dalam satu sesi wawancara yang dijalankan dari Oktober 2006 hingga Mac 2007 oleh Yayasan Kepimpinan Perdana, mantan Perdana Menteri Malaysia Tun Dr Mahathir Mohamad telah ditanya sama ada Dasar Pendidikan Kebangsaan telah mencapai matlamatnya ataupun tidak dalam tempoh 22 tahun pentadbiran beliau. Ini kerana, ketika Tun Dr Mahathir Mohamad mengambil alih jawatan Menteri Pendidikan pada tahun 1974, banyak usaha telah dilakukan oleh beliau terutamanya untuk mengubah model pendidikan British kepada model pendidikan Jerman. Model pendidikan Jerman dilihat lebih authentic serta menekankan kepada hands-on terutamanya dalam pendidikan kejuruteraan yang pada pandangan beliau amat baik untuk pembangunan Malaysia ke arah negara maju (Yayasan Kepimpinan Perdana, 2014).

Namun, jawapan daripada Tun Dr Mahathir Mohamad menyatakan beliau tidak berjaya sepenuhnya untuk menukar sistem British kepada sistem Jerman terutamanya dalam pendidikan kejuruteraan di Malaysia. Menurut beliau lagi, kerajaan melalui Kementerian Pendidikan Malaysia perlu meneruskan usaha mengenalpasti kaedah pendidikan yang lebih berkesan melalui cara Jerman yang lebih authentic serta hands-on. Selanjutnya, beliau menjelaskan seperti berikut;

"Melalui sistem Jerman, kita mempraktikkan sesuatu yang kita pelajari. Kita membuktikan dengan cara yang lebih jelas dengan melakukan sesuatu kerja itu sendiri. Sebab itu kita dapati orang Jerman begitu cekap dalam bidang seperti kejuruteraan. Tetapi kita masih mendapati Malaysia lebih menjurus kepada sistem pembelajaran secara teori, sistem peperiksaan bertulis ataupun secara lisan tanpa membuktikan kebolehan mereka membuat sesuatu itu secara praktikal. 
Matlamat ini perlu diteruskan kerana jika kita ingin bersaing dengan bangsa-bangsa lain, kecekapan dan kebolehan kita secara praktikal perlu dibuktikan”. (Yayasan Kepimpinan Perdana, pp.54, 2014)

Selain itu, Sistem Latihan Dua Hala Nasional (SLDN) yang terhasil daripada kerjasama di antara negara Malaysia dan Jerman sejak tahun 1996 menunjukkan kesungguhan kerajaan ke arah sistem pendidikan yang lebih authentic mengikut model pendidikan negara Jerman. Kabinet Malaysia telah meluluskan perlaksanaan SLDN pada 19 Mei 2004 dan mula diaplikasikan pada tahun 2005. Sasaran awal SLDN adalah untuk menghasilkan sejumlah 31,500 pekerja mahir menjelang tahun 2010 (MLVK, 2005). Sehingga kini, SLDN turut dijalankan seiring dengan transformasi Politeknik Malaysia bermula pada tahun 2010 bagi memperkasakan program pendidikan kejuruteraan yang lebih berfokuskan kepada sistem Pendidikan Teknikal dan Latihan Vokasional (Jabatan Pengajian Politeknik, 2013). Melalui SLDN, keutamaan yang diberikan adalah untuk menghasilkan tenaga kerja yang berketerampilan, mempunyai pengetahuan yang pelbagai serta mempunyai minat untuk terus belajar bagi meningkatkan bekalan tenaga kerja mahir dan berpengetahuan melalui program pembangunan pendidikan dan latihan. Di samping itu, pengoperasiannya juga menekankan bahawa perlu wujudnya kerjasama yang erat di antara institusi pengajian tinggi dan industri bagi memastikan kurikulum yang digunakan sentiasa releven dengan keperluan semasa (Akhmal, Rohana \& Amimudin, 2011).

Sehubungan dengan itu, untuk menghasilkan jurutera dan modal insan teknikal yang berkualiti seiring dengan keperluan semasa, pendekatan Pengajaran dan Pembelajaran (P\&P) secara authentic learning perlu diterapkan secara menyeluruh ke dalam sistem pendidikan negara terutamanya dalam pendidikan kejuruteraan. Graduan dalam bidang pendidikan kejuruteraan yang bakal dihasilkan sewajarnya mempunyai kecekapan dan kebolehan yang tinggi hasil daripada aktiviti yang dilakukan secara hands-on di institusi pengajian tinggi. Melalui pendekatan P\&P secara authentic learning, pembinaan pengetahuan serta kemahiran dapat dilakukan dengan lebih praktikal. Menurut Bennett, Agostinho \& Lockyer 
(2005); Borthwick, Bennett, Lefoe \& Huber (2007); dan Wagner (2008), authentic learning merupakan pendekatan P\&P yang dapat menghubungkan pelajar dengan dunia sebenar.

Selain itu, authentic learning mengambilkira perspektif pelajar dengan menyesuaikan kandungan pembelajaran untuk menjadikannya lebih bermakna melalui tugas-tugas yang berkaitan dalam situasi kehidupan sebenar (Andersson \& Andersson, 2005). Dalam persekitaran pembelajaran ini, pelajar bukan sahaja memperolehi pengetahuan, tetapi juga dapat mengaitkannya dengan konteks dunia sebenar melalui nilai-nilai yang telah diterapkan dan secara tidak langsung membentuk pengalaman yang berharga untuk diri mereka sendiri (Granton \& Garusetta, 2004). Kemahiran kebolehpasaran juga dapat dibentuk serta diterapkan sesuai dengan keperluan semasa melalui pendekatan authentic learning kerana pembinaan pengetahuan dan kemahiran pelajar di institusi pengajian tinggi adalah seiring dengan keperluan pasaran kerja (Ferns, 2012). Justeru itu, kajian ini dijalankan bagi mendukung usaha kerajaan untuk meneruskan matlamat melahirkan jurutera dan modal insan teknikal yang berkualiti melalui pendekatan pengajaran secara authentic learning.

\section{Pengajaran \& Pembelajaran Secara Authentic Learning}

Sistem pendidikan tradisional yang lebih berpusatkan guru didapati terlalu pasif dan sederhana kesannya kepada pembinaan pengetahuan pelajar (Jonassen, Strobel \& Lee, 2006), di samping aktiviti pembelajaran yang hanya dilaksanakan di dalam kelas secara perkuliahan (Nicaise, Gibney, \& Crane, 2000). Kenyataan ini turut disokong oleh Rule (2006), dan Herrington, Reeves \& Oliver (2006), yang menyatakan bahawa pembelajaran berpusatkan guru memberikan impak yang negatif kerana pelajar kurang berinisiatif dalam pembelajaran mereka. Oleh sebab itulah pembelajaran secara authentic learning yang berpusatkan pelajar ini merupakan suatu pendekatan yang amat penting dalam sistem pendidikan di negaranegara maju seperti Jerman dan Amerika Syarikat dalam melahirkan modal insan yang kreatif, inovatif, berdaya saing, serta berkemahiran tinggi (Revington, 2012). 
Persekitaran pembelajaran secara authentic learning pada asasnya berlandaskan kepada teori konstruktivisme yang memberi ruang dan peluang kepada pelajar membina pengetahuan secara aktif dengan mengintegrasikan pengalaman sedia ada kepada pengalaman semasa bagi membentuk pengetahuan yang baru (Parker, Maor \& Herrington, 2013). Oleh itu, pembelajaran secara authentic learning diperlukan bagi menambahbaik kualiti pembelajaran di dalam kelas bagi membentuk kefahaman dan pengetahuan pelajar yang lebih konkrit berasaskan kepada teori konstruktivisme (Barab, Squire \& Dueber, 2000). Menurut Herrington \& Oliver (2000), reka bentuk program pembelajaran yang berorientasikan prinsip konstruktivisme hanya dapat dilaksanakan dalam persekitaran pembelajaran secara authentic learning.

Aktiviti pembelajaran secara authentic learning adalah amat penting untuk membantu pelajar dalam memahami pelbagai cabaran dunia luar di dalam persekitaran pembelajaran. Herrington \& Oliver (2000), berpendapat bahawa penglibatan pelajar dalam aktivitiaktiviti secara authentic learning adalah sumber utama pengetahuan yang lebih bermakna daripada sumber pengetahuan yang hanya didapati secara teori melalui perkuliahan dan buku-buku yang dirujuk. Ini telah ditegaskan oleh ahli falsafah konstuktivisme (Von Glasersfeld, 1998), bahawa pelajar sendiri yang dapat membina pengetahuan mereka melalui pengalaman yang dilalui. Peranan aktiviti psikomotor dalam proses pembelajaran bukan lagi sematamata untuk menyediakan latihan secara amali di dalam kelas, malahan perlu melangkaui aktiviti di luar kelas (Revington, 2012).

Selain itu, Reeves, Herrington \& Olivers (2002) berpendapat bahawa mendapatkan definisi secara teori tidak lagi memadai dalam pembelajaran secara authentic learning. Sebaliknya, aktiviti-aktiviti yang dilaksanakan melalui pembelajaran secara authentic learning mampu mendefinisikan sebarang takrifan dengan lebih tepat serta sesuai dengan dunia nyata seperti yang dijelaskan oleh Herrington \& Oliver (2000). Oleh itu, dalam pembelajaran secara authentic learning, pelajar perlu dibenarkan untuk mengakses rangka kerja yang benar-benar digunakan oleh pengamal atau pakar dalam sesuatu bidang itu (Lombardi, 2007). 
Pengalaman pembelajaran secara authentic learning membolehkan pelajar untuk menggabungkan konsep-konsep dan teori-teori daripada pendidikan formal dan menerapkannya pada amalan dunia sebenar (Bennett, et al., 2005; Borthwick, et al., 2007). Pelajar juga boleh membina identiti mereka melalui aktiviti sosial kerana mereka berada dalam dunia nyata melalui pembelajaran secara authentic learning (Murphy, 2009). Selain itu, pelajar bermotivasi dengan melaksanakan tugas-tugas pekerjaan yang sebenarnya dan menghasilkan produk yang mencerminkan siapa mereka dan apa yang mereka percaya (Wagner, 2008).

Stein, Isaacs \& Andrews (2004), berpendapat bahawa semua bakal jurutera, ahli sejarah, para ilmuan atau sesiapa sahaja yang akan menceburi bidang profesional memerlukan pembudayaan disiplin yang ketat dalam bidang masing-masing di peringkat awal pembelajaran mereka. Mereka juga menyatakan bahawa pelajar perlu menguasai elemen-elemen asas dalam sesuatu bidang. Dalam usaha untuk menguasai elemen-elemen asas tersebut, keyakinan perlu diberi kepada pelajar baru yang menceburi sesuatu bidang itu dengan mengiktiraf mereka sebagai 'peserta yang sah' dan layak membina pengetahuan melalui aktiviti pembelajaran secara authentic learning di sepanjang pengajian mereka. Melalui pembelajaran secara authentic learning, pelajar lebih cenderung untuk mempercayai bahawa setiap masalah pasti ada jawapannya dan cara penyelesaiannya mungkin boleh dipelbagaikan. Ini kerana, aktiviti pembelajaran secara authentic learning merangkumi ketidakpastian, kesukaran dan perspektif yang bertentangan membantu pelajar untuk mengembangkan kemahiran menyelesaikan masalah mereka sepertimana yang digunakan oleh pakar dalam bidang tersebut. Lombardi (2007) juga berpendapat bahawa, lebih banyak pendedahan diberikan kepada pelajar terhadap persekitaran dunia sebenar, lebih cepat pelajar membina pengetahuan dan kemahiran mereka sepertimana yang dilakukan oleh golongan profesional.

Namun begitu, walaupun pembelajaran secara authentic learning di institusi pengajian tinggi telah mula mendapat perhatian sejak tahun 1980-an lagi (Rule, 2006), perlaksanaannya tidak menyeluruh kerana masih ada jurang antara teori pendidikan dan praktik pengajaran (Herrington, Reeves, \& Oliver, 2006), dan di antara 
pengalaman pembelajaran di institusi pengajian tinggi dengan penggunaan pembelajaran di dunia sebenar (Stein, Isaacs, \& Andrews, 2004). Dalam konteks pendidikan di Malaysia, pendekatan authentic learning ini masih diperingkat permulaan kerana lebih berorientasikan sistem peperiksaan (Yayasan Kepimpinan Perdana, 2014).

Sehubungan dengan itu, kesungguhan kerajaan dalam memperkasakan sistem penyampaian di politeknik dapat dilihat apabila transformasi politeknik merupakan salah satu daripada Projek Agenda Kritikal (Critical Agenda Project - CAP) yang telah dilaksanakan di peringkat nasional. Perubahan ini telah diperkasakan dengan Dasar Hala Tuju Transformasi Politeknik: Ke Arah Kelestarian Penghasilan Modal Insan Negara. Dasar ini bertujuan untuk membawa perubahan sistematik yang menjurus kepada pewujudan institusi pilihan (preferred institution), penghasilan graduan yang boleh diambil bekerja (employable graduates) dan pembinaan persepsi positif dalam kalangan masyarakat terhadap pendidikan Politeknik (Kementerian Pengajian Tinggi, 2013). Justeru, untuk mencapai agenda transformasi ini, kaedah penyampaian pengajaran para pensyarah juga perlulah dilakukan secara lebih berkesan melalui pendekatan pengajaran secara authentic learning.

Oleh yang demikian, kajian ini dijalankan untuk membangunkan sebuah model pengajaran authentic learning yang dinamakan sebagai model MPAL. Model ini boleh digunakan sebagai garis panduan kepada para pensyarah Politeknik Malaysia dalam melaksanakan aktiviti pengajaran secara authentic learning. Pembangunan model ini adalah dengan menggunakan aplikasi Interpretive Structural Modelling (ISM).

\section{OBJEKTIF KAJIAN}

Objektif yang ingin dicapai dalam kajian ini adalah seperti berikut:

1. Mengenal pasti elemen authentic learning dalam model Malaysian Polytechnics Authentic Learning (MPAL) Program Kejuruteraan Politeknik Malaysia.

2. Membangunkan model Malaysian Polytechnics Authentic Learning (MPAL) Program Kejuruteraan Politeknik Malaysia. 
3. Menilai model Malaysian Polytechnics Authentic Learning (MPAL) Program Kejuruteraan Politeknik Malaysia.

\section{METODOLOGI}

Fokus kajian ini adalah untuk membangunkan sebuah model berstruktur yang boleh ditafsirkan (interpretive structural model) yang berbentuk authentic learning bagi program kejuruteraan Politeknik Malaysia. Aplikasi Interpretive Structural Modelling (ISM) digunakan bagi pembangunan model Malaysian Polytechnics Authentic Learning (MPAL).

ISM adalah satu proses interaksi berbantukan komputer untuk membolehkan individu atau kumpulan membangunkan model atau peta hubungan antara elemen-elemen yang terlibat dalam sesuatu isu yang dikaji. Penggunaan perisisan ISM ini antara lain adalah untuk merungkai satu sistem yang kompleks kepada beberapa subsistem menggunakan pengalaman praktikal dan pengetahuan pakar bagi membina Model Struktur Berhierarki (Multilevel Structural Model). Selain itu, ISM juga boleh digunakan untuk mengenalpasti dan menganalisis hubungan antara pembolehubah tertentu bagi mentakrifkan sesuatu masalah tersebut (Warfield, 1974; Sage, 1977; Janes, 1988; Warfield \& Perino, 1999). Dalam kajian ini, perisian ISM digunakan untuk membangunkan model MPAL dalam bentuk langkah demi langkah, serta hubungan setiap elemen yang telah dikenalpasti oleh panel pakar bagi melaksanakan pendekatan pengajaran secara authentic learning.

Bagi mencapai ketiga-tiga objektif kajian yang ditetapkan, pembangunan model MPAL adalah berdasarkan kepada pandangan serta keputusan bersepadu yang dibuat oleh panel pakar yang dilantik. Panel pakar yang sama akan mengenalpasti elemen-elemen authentic learning yang sesuai dalam model MPAL, membangunkan model MPAL melalui sesi ISM dan menilai semula kesesuaian model yang dihasilkan.

Pemilihan panel pakar yang sesuai adalah sangat penting dalam kajian ini kerana semua dapatan yang diperolehi adalah berdasarkan kepada pandangan serta keputusan bersepadu yang dibuat oleh 
mereka. Di samping itu, panel pakar perlulah terdiri daripada beberapa orang individu yang mempunyai pengetahuan yang luas di dalam bidang-bidang tertentu (Hartman \& Krahn, 2007). Adler \& Ziglio (1996), menegaskan bahawa pemilihan panel pakar perlulah berdasarkan kepada empat keperluan 'kepakaran' seperti berikut: i) Berpengetahuan serta berpengalaman dalam isu atau permasalahan yang dikaji; ii) Berkeupayaan serta bersedia untuk memberi komitmen sepanjang kajian dijalankan; iii) Boleh memperuntukkan masa yang mencukupi untuk mengambil bahagian dalam kajian yang dijalankan; dan iv) Mempunyai kemahiran berkomunikasi yang berkesan. Dalam kajian ini, pengkaji memilih panel pakar berdasarkan kepada empat kriteria setelah mengambilkira pandangan daripada Adler \& Ziglio (1996) iaitu: i) Panel pakar yang mewakili Politeknik dan Jabatan Pengajian Politeknik perlulah terlibat secara langsung dalam sistem pengajian Politeknik dengan pengalaman sekurang-kurangnya 10 tahun; ii) Panel pakar yang mewakili Politeknik dan Jabatan Pengajian Politeknik perlulah dalam bidang pengurusan sekurang-kurangnya dengan jawatan Ketua Jabatan; iii) Panel pakar yang mewakili Politeknik dan Jabatan Pengajian Politeknik perlulah mempunyai pengalaman mengajar di Politeknik sekurang-kurangnya 5 tahun sebelum diserap ke jawatan pengurusan; dan iv) Panel pakar yang mewakili industri perlulah daripada alumni Politeknik yang telah berjaya dalam bidang masing-masing hasil daripada sistem pengajian Politeknik Malaysia.

Selain itu, antara pertimbangan yang penting untuk menjalankan sesi ISM adalah jumlah bilangan pakar yang terlibat. Menurut Janes (1988), jumlah bilangan pakar untuk kajian yang melibatkan sesi ISM adalah terhad kepada maksimum lapan orang sahaja. Ini kerana, apabila setiap individu pakar berinteraksi dengan pakar yang lain, perbahasan akan berlaku untuk mencapai kata sepakat. Janes menyatakan, apabila jumlah pakar yang terlibat terlalu ramai, kualiti perbahasan juga akan terganggu oleh faktorfaktor lain seperti keletihan, wujudnya emosi yang kurang baik, hilang minat untuk berbincang, pandangan tertumpu kepada satu pihak sahaja dan akhirnya keputusan yang diambil tidak mewakili keseluruhan pandangan panel pakar. Berdasarkan kepada formula kebarangkalian $\mathrm{n}(\mathrm{n}-1)$, dengan $\mathrm{n}$ adalah bilangan pakar, didapati bahawa kebarangkalian wujudnya komunikasi dalam bentuk 
perbahasan di kalangan panel pakar akan meningkat dengan bertambahnya bilangan pakar yang dilantik. Sebagai contoh, jika jumlah panel pakar adalah seramai enam orang, kebarangkalian wujudnya komunikasi di kalangan mereka adalah sebanyak 6(6-1) $=30$. Jika ditambah empat orang pakar, kebarangkalian wujudnya komunikasi akan meningkat sebanyak $10(10-1)=90$. Oleh itu, jumlah panel pakar dalam sesi ISM ini dihadkan kepada maksimun lapan orang sahaja bagi memastikan kualiti daripada sesi ISM yang dijalankan tidak terjejas.

Justeru itu, kajian ini menggunakan tujuh orang panel pakar. Seramai dua orang pakar mewakili Politeknik, tiga orang pakar mewakili Jabatan Pengajian Politeknik dan dua orang pakar mewakili industri. Jadual 1 menunjukkan pecahan panel pakar yang dilantik.

Jadual 1

Senarai Panel Pakar

\begin{tabular}{|c|c|c|c|}
\hline Institusi & $\begin{array}{l}\text { Bil. } \\
\text { Pakar }\end{array}$ & Bahagian & Jawatan \\
\hline \multirow[t]{2}{*}{ Politeknik } & 1 & $\begin{array}{l}\text { Politeknik Konven- } \\
\text { sional }\end{array}$ & Ketua Jabatan, Gred DH48 \\
\hline & 1 & Politeknik Premier & Ketua Jabatan, Gred DH48 \\
\hline \multirow[t]{3}{*}{$\begin{array}{l}\text { Jabatan Pengajian } \\
\text { Politeknik }\end{array}$} & 1 & Kurikulum & $\begin{array}{l}\text { Penolong Pengarah Kanan, } \\
\text { Gred DH48 }\end{array}$ \\
\hline & 1 & Dasar & $\begin{array}{l}\text { Penolong Pengarah Kanan, } \\
\text { Gred DH48 }\end{array}$ \\
\hline & 1 & $\begin{array}{l}\text { Hubungan Industri \& } \\
\text { Kebolehpasaran }\end{array}$ & $\begin{array}{l}\text { Penolong Pengarah Kanan, } \\
\text { Gred DH48 }\end{array}$ \\
\hline \multirow[t]{2}{*}{ Industri } & 1 & Syarikat Automotif & Pengarah Urusan \\
\hline & 1 & Syarikat Perkilangan & Pengarah Urusan \\
\hline
\end{tabular}

Terdapat enam langkah utama dalam pembangunan model MPAL dengan menggunakan aplikasi ISM. Secara ringkasnya, pembangunan model bermula dengan mengenalpasti elemenelemen authentic learning yang berkaitan oleh panel pakar yang dilantik. Langkah kedua menentukan context dan relation dalam aplikasi ISM. Langkah ketiga membangunkan Structural SelfInteraction Matrix (SSIM). Langkah keempat menjana model MPAL dengan aplikasi ISM. Langkah kelima menilai model MPAL 
yang dihasilkan. Akhirnya, model lengkap MPAL dipersembahkan setelah melalui proses penilaian. Perincian langkah-langkah dalam pembangunan model MPAL dengan menggunakan aplikasi ISM adalah seperti berikut:

Langkah 1: Mengenal pasti elemen pengajaran berbentuk authentic learning yang boleh disesuaikan dengan kurikulum Politeknik Malaysia. Dalam kajian ini, kaedah Nominal Group Technique (NGT) yang diubahsuai digunakan untuk mengenal pasti elemen authentic learning yang dikemukakan oleh panel pakar. NGT klasik (Delbecq, 1975) adalah satu proses yang berulang untuk mengintegrasikan pelbagai pendapat individu untuk mencapai kata sepakat dalam isu yang diperbincangkan. Oleh itu, ia mengambil masa yang lebih lama. Kaedah NGT diubahsuai bermula dengan senarai rujukan elemen authentic learning yang dikemukakan berdasarkan kepada kajian terdahulu. Proses ini penting untuk memberi gambaran yang jelas kepada panel pakar yang terlibat dalam sesi ISM untuk menjana idea mereka secara optimum bagi membangunkan model MPAL. Secara tidak langsung, senarai rujukan ini menyediakan penerangan mengenai skop kajian di samping bertujuan untuk mencetuskan idea awal di kalangan panel pakar. Kaedah ini dapat memendekkan masa proses NGT klasik daripada 4 jam kepada hanya 90 minit sahaja. Dalam skop kajian ini, terdapat tiga sumber rujukan utama bagi membentuk elemen authentic learning dan enam model authentic learning yang dirujuk daripada sorotan kajian lepas. Rujukan tersebut adalah seperti berikut: i) Sembilan elemen authentic learning (Herrington \& Oliver, 2000); ii) Tujuh tugasan authentic learning (Borthwick et al., 2007); iii) Empat tema authentic learning (Rule, 2006); dan iv) Enam model authentic learning: Model Parker, Maor \& Herrington (2013), Model Revington (2012), Model Herrington, Reeves \& Oliver (2010), Model Webb (2009), Model Lombardi (2007) dan Model Stein, Isaacs \& Andrew (2004).

Semasa proses NGT, panel pakar boleh bersetuju atau tidak bersetuju dengan senarai aktiviti authentic learning yang telah dikemukakan. Panel pakar juga boleh menambah idea-idea lain yang difikirkan sesuai untuk pembangunan model. Aktiviti yang mencapai kata sepakat positif akan dimasukkan ke dalam model MPAL. 
Langkah 2: Menentukan hubungan di antara konteks (context) dan kaitan (relation) bagi setiap elemen yang telah diperolehi dalam Langkah 1. Hubungan ini dilakukan dengan menggunakan frasa yang paling sesuai yang dapat menggambarkan bagaimana setiap elemen itu dapat dikaitkan di antara satu sama lain. Dalam erti kata lain, hubungan konteks dan kaitan ini dapat menetapkan matlamat yang akan dicapai dengan memberi tumpuan kepada perkaitan setiap elemen bagi membentuk model MPAL. Dalam kajian ini, hubungan konteks dan kaitan ditentukan oleh panel pakar.

Langkah 3: Membangunkan Structural Self-Interaction Matrix (SSIM) dengan menggunakan aplikasi ISM. SSIM dapat menunjukkan hubungan di antara setiap elemen dalam bentuk model lengkap. Dalam pembangunan SSIM, dua elemen dalam bentuk pasangan dipaparkan oleh perisian ISM untuk membenarkan panel pakar membuat keputusan melalui proses pengundian. Proses ini diulang sehingga semua unsur-unsur yang dipasangkan selesai diundi oleh panel pakar.

Langkah 4: Menjana model MPAL. Proses ini dilakukan oleh perisian ISM selepas kesemua pasangan elemen diundi oleh panel pakar. Perisian ISM membina model berasaskan konsep perbandingan di antara pasangan (dua elemen) secara logik transitif. Logik transitif menyatakan bahawa, bagi mana-mana tiga elemen (A, B, C) dengan hubungan yang diberikan apabila:

- $\quad$ A mempunyai hubungan dengan $\mathrm{B}$, (ditulis $\mathrm{A} \rightarrow \mathrm{B}$ ).

- $\quad$ B mempunyai hubungan kepada $\mathrm{C}$, (ditulis $\mathrm{B} \rightarrow \mathrm{C}$ ).

- $\quad$ A mempunyai hubungan dengan $\mathrm{C}$, (ditulis $\mathrm{A} \rightarrow \mathrm{C}$ atau $\mathrm{A} \rightarrow$ $\mathrm{B} \rightarrow \mathrm{C})$.

Langkah 5: Model ini kemudiannya dinilai semula oleh panel pakar untuk memperbaiki hubungan di antara elemen dan membuat pengubahsuaian yang perlu.

Langkah 6: Model akhir kemudiannya dibentangkan selepas pengubahsuaian dibuat. Rajah 1 menunjukkan carta alir bagi setiap langkah yang digunakan dalam kajian ini. 


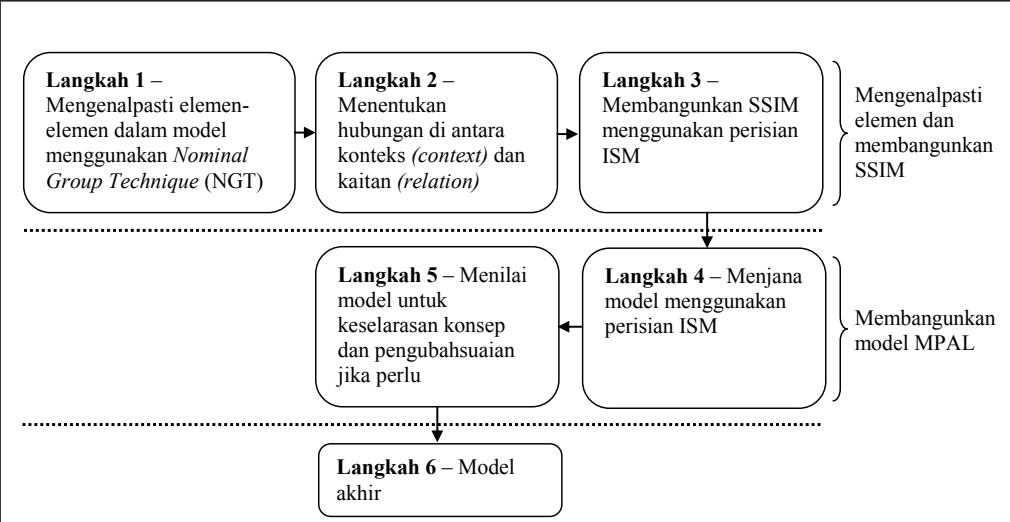

Rajah 1. Carta Alir Pembangunan Model MPAL

\section{DAPATAN KAJIAN}

Dapatan daripada Langkah 1 - Jadual 2 menunjukkan senarai elemen yang perlu ada dalam model MPAL bagi melaksanakan aktiviti pengajaran secara authentic learning. Susunan elemen ini berdasarkan kepada pandangan serta keputusan panel pakar setelah melalui proses NGT.

\section{Jadual 2}

Susunan Elemen dalam Model MPAL setelah melalui Proses NGT

No.

Elemen Model MPAL

\section{Elemen}

1 Kolaborasi antara politeknik, industri dan masyarakat setempat.

2 Surat permohonan rasmi politeknik; surat kebenaran industri; surat pelepasan pelajar.

3 Taklimat daripada pensyarah dan industri kepada pelajar.

4 Rubrik diberikan kepada pelajar dan industri sebelum aktiviti dijalankan.

$5 \quad$ Aktiviti perlu dalam skop yang jelas supaya disiplin ilmu dalam bidang tertentu dapat dipupuk secara bersepadu.

6 Aktiviti yang diberi mampu menghubungkan pengetahuan sedia ada pelajar dengan pengetahuan baru. 


\begin{tabular}{cl}
\hline $\begin{array}{c}\text { No. } \\
\text { Elemen }\end{array}$ & \multicolumn{1}{c}{ Elemen Model MPAL } \\
\hline 7 & Aktiviti yang kompleks dipecahkan kepada sub-aktiviti oleh pelajar. \\
8 & $\begin{array}{l}\text { Aktiviti dapat menggalakkan pelajar berhubung dengan dunia luar / } \\
\text { menyelesaikan isu-isu semasa / memperkukuhkan pengalaman pelajar. }\end{array}$ \\
9 & $\begin{array}{l}\text { Aktiviti disokong dengan menyediakan sumber yang pelbagai } \\
\text { (contohnya senarai tempat dan pakar yang boleh dirujuk). }\end{array}$ \\
10 & $\begin{array}{l}\text { Aktiviti dilakukan secara kolaborasi bagi mendapatkan pelbagai } \\
\text { perspektif. }\end{array}$ \\
11 & $\begin{array}{l}\text { Menyediakan bimbingan kepada pelajar pada masa yang kritikal dan } \\
\text { mendorong pelajar dengan pelbagai pendekatan. }\end{array}$ \\
12 & $\begin{array}{l}\text { Menggalakkan refleksi daripada pelajar. } \\
\text { Penilaian secara authentic assessment. }\end{array}$ \\
\hline
\end{tabular}

Dapatan daripada Langkah 2 - Berdasarkan kepada objektif kajian, panel pakar telah mengenal pasti konteks (context) dan kaitan (relation) yang bersesuaian. Dalam kajian ini, context yang dipersetujui adalah 'untuk menjalankan pengajaran secara authentic learning, ADAKAH elemen...' dan relation 'LEBIH UTAMA daripada...' telah dipilih. Secara ringkas, hubungan di antara context dan relation ini merupakan perkaitan kepentingan bagi setiap elemen mengikut keutamaan. Rajah 2 menunjukkan context dan relation yang telah dipersetujui oleh panel pakar dan ditetapkan dalam perisian ISM.

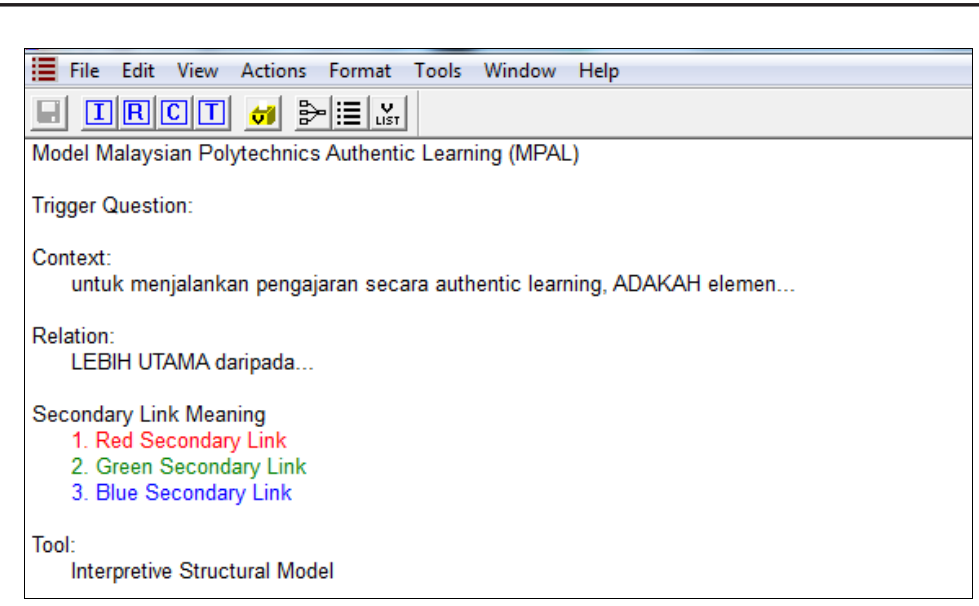

Rajah 2. Context dan Relation dalam Perisian ISM 
Dapatan daripada Langkah 3, 4, 5, 6 - Kesemua langkah ini adalah untuk membangunkan model MPAL menerusi pandangan serta keputusan panel pakar. Pembangunan model ini adalah melalui perkaitan di antara setiap undian pasangan elemen dengan bantuan perisian ISM seperti yang telah dibincangkan dalam metodologi kajian. Setelah model dibangunkan, model ini kemudiannya dinilai semula oleh panel pakar untuk memperbaiki hubungan di antara elemen dan membuat pengubahsuaian yang perlu.

Dapatan daripada penilaian panel pakar - Model MPAL yang telah dibangunkan melalui langkah 3, 4, 5 dan 6 ini telah dipersetujui oleh semua panel pakar tanpa sebarang pengubahsuaian ke atas penambahan atau pengurangan elemen. Namun begitu, panel pakar bersepakat untuk membahagikan model MPAL yang telah dibangunkan kepada tiga fasa utama iaitu FASA 1 (Fasa Permulaan), FASA 2 (Fasa Perlaksanaan) dan FASA 3 (Fasa Penilaian). Terdapat empat elemen dalam FASA 1, tujuh elemen dalam FASA 2 dan dua elemen dalam FASA 3. Jadual 3 menunjukkan elemen-elemen mengikut susunan dalam model MPAL bagi setiap fasa setelah melalui penilaian panel pakar.

Jadual 3

Elemen-elemen dalam Model MPAL bagi Setiap Fasa Setelah Melalui Penilaian Panel Pakar

\begin{tabular}{cccl}
\hline Fasa & $\begin{array}{c}\text { No. } \\
\text { Elemen } \\
\text { NGT }\end{array}$ & $\begin{array}{c}\text { No. Susunan } \\
\text { Elemen dalam } \\
\text { Model MPAL }\end{array}$ & Elemen Model MPAL \\
\hline 1 & 1 & 1 & $\begin{array}{l}\text { Kolaborasi antara politeknik, industri } \\
\text { dan masyarakat setempat. }\end{array}$ \\
& 2 & 2 & $\begin{array}{l}\text { Surat permohonan rasmi politeknik; } \\
\text { surat kebenaran industri; surat } \\
\text { pelepasan pelajar. } \\
\text { (Permulaan) }\end{array}$ \\
& 3 & 3 & $\begin{array}{l}\text { Taklimat daripada pensyarah dan } \\
\text { industri kepada pelajar. } \\
\text { Rubrik diberikan kepada pelajar dan } \\
\text { industri sebelum aktiviti dijalankan. }\end{array}$ \\
& 3 & 3 &
\end{tabular}




\begin{tabular}{|c|c|c|c|}
\hline Fasa & $\begin{array}{l}\text { No. } \\
\text { Elemen } \\
\text { NGT }\end{array}$ & $\begin{array}{l}\text { No. Susunan } \\
\text { Elemen dalam } \\
\text { Model MPAL }\end{array}$ & Elemen Model MPAL \\
\hline \multirow[t]{7}{*}{$\begin{array}{c}2 \\
\text { (Perlaksanaan) }\end{array}$} & 11 & 4 & $\begin{array}{l}\text { Menyediakan bimbingan kepada } \\
\text { pelajar pada masa yang kritikal dan } \\
\text { mendorong pelajar dengan pelbagai } \\
\text { pendekatan. }\end{array}$ \\
\hline & 5 & 5 & $\begin{array}{l}\text { Aktiviti perlu dalam skop yang } \\
\text { jelas supaya disiplin ilmu dalam } \\
\text { bidang tertentu dapat dipupuk secara } \\
\text { bersepadu. }\end{array}$ \\
\hline & 9 & 5 & $\begin{array}{l}\text { Aktiviti disokong dengan } \\
\text { menyediakan sumber yang pelbagai } \\
\text { (contohnya senarai tempat dan pakar } \\
\text { yang boleh dirujuk). }\end{array}$ \\
\hline & 6 & 6 & $\begin{array}{l}\text { Aktiviti yang diberi mampu } \\
\text { menghubungkan pengetahuan sedia } \\
\text { ada pelajar dengan pengetahuan baru. }\end{array}$ \\
\hline & 7 & 6 & $\begin{array}{l}\text { Aktiviti yang kompleks dipecahkan } \\
\text { kepada sub-aktiviti oleh pelajar. }\end{array}$ \\
\hline & 8 & 6 & $\begin{array}{l}\text { Aktiviti dapat menggalakkan pelajar } \\
\text { berhubung dengan dunia luar / } \\
\text { menyelesaikan isu-isu semasa / } \\
\text { memperkukuhkan pengalaman pelajar. }\end{array}$ \\
\hline & 10 & 7 & $\begin{array}{l}\text { Aktiviti dilakukan secara kolaborasi } \\
\text { bagi mendapatkan pelbagai perspektif. }\end{array}$ \\
\hline \multirow[t]{2}{*}{$\begin{array}{c}3 \\
\text { (Penilaian) }\end{array}$} & 12 & 8 & $\begin{array}{l}\text { Menggalakkan refleksi daripada } \\
\text { pelajar. }\end{array}$ \\
\hline & 13 & 8 & Penilaian secara authentic assessment. \\
\hline
\end{tabular}

Rajah 3 menunjukkan model lengkap MPAL yang telah dibangunkan dengan menggunakan aplikasi ISM. Arah anak panah (arrow) menunjukkan logik transitif yang berlaku dalam perisian ISM hasil daripada hubungan di antara konteks (context) dan kaitan (relation) bagi setiap elemen seperti yang telah dijelaskan dalam metodologi kajian. 


\begin{tabular}{|c|c|}
\hline $\begin{array}{l}\text { 1. Kolaborasi antara } \\
\text { politeknik, industri dan } \\
\text { masyarakat setempat. }\end{array}$ & $\begin{array}{l}\text { 2. Surat permohonan rasmi } \\
\text { politeknik; surat kebenaran } \\
\text { industri; surat pelepasan } \\
\text { pelajar. }\end{array}$ \\
\hline
\end{tabular}

FASA 1 (Fasa Permulaan)

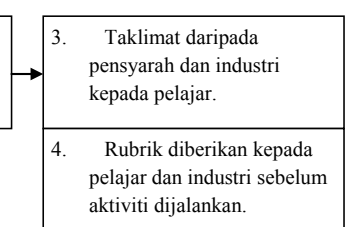
aktiviti dijalankan.

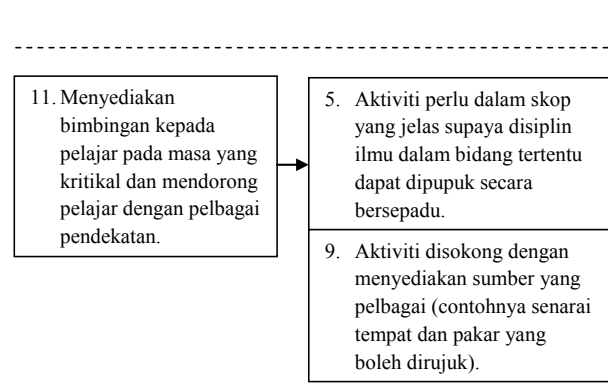

FASA 2 (Fasa Perlaksanaan)

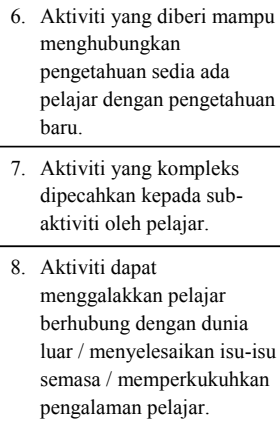

6. Aktiviti yang diberi mampu menghubungkan pengetahuan sedia ada pelajar dengan pengetahuan baru.

7. Aktiviti yang kompleks dipecahkan kepada subaktiviti oleh pelajar.

8. Aktiviti dapat menggalakkan pelajar berhubung dengan dunia luar / menyelesaikan isu-isu semasa / memperkukuhkan pengalaman pelajar.

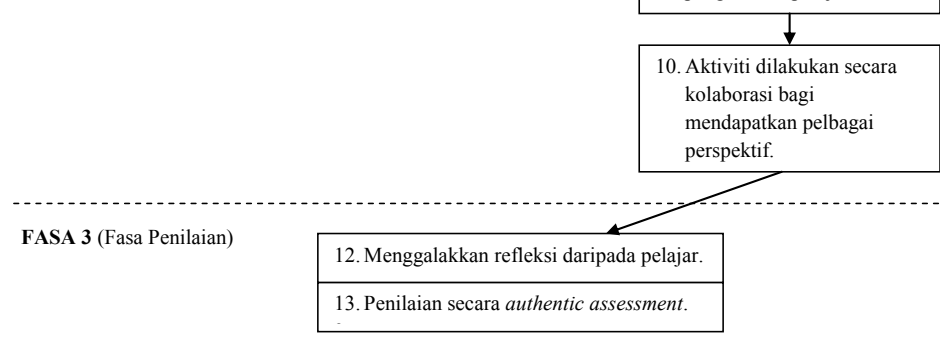

Rajah 3: Model Malaysian Polytechnics Authentic Learning (MPAL) bagi Program Kejuruteraan Politeknik Malaysia dengan Menggunakan Aplikasi Interpretive Structural Modelling (ISM)

\section{PERBINCANGAN}

Model MPAL menunjukkan dengan jelas elemen-elemen utama yang perlu diberi penekanan untuk melaksanakan pendekatan pengajaran secara authentic learning. Model MPAL bermula dengan FASA 1 yang dikenali sebagai Fasa Permulaan. Dalam Fasa Permulaan, panel pakar bersetuju untuk membuat 'penetapan' atau 'setup' awalan terhadap sebarang aktiviti pengajaran secara authentic learning bermula daripada peringkat pengurusan tertinggi politeknik. Ini kerana, hanya pihak pengurusan tertinggi politeknik 
sahaja yang dapat memastikan usaha merealisasikan pendekatan pengajaran secara authentic learning ini dapat dimulakan dan seterusnya ditambah baik.

Dalam satu kajian di sebuah sekolah tinggi awam yang telah berjaya melaksanakan pendekatan pengajaran secara authentic learning yang bertajuk 'Authentic Instruction for 21st Century Learning: Higher Order Thinking in an Inclusive School', dapatan kajian menyatakan pengurusan sekolah perlu bekerjasama sepenuhnya bagi menjayakan perlaksanaan pengajaran secara authentic learning (Betty, 2012). Justeru, dapatan kajian ini juga selari dengan dapatan kajian Betty (2012) apabila panel pakar juga bersetuju kolaborasi antara politeknik, industri dan masyarakat setempat (Elemen 1) perlu dilaksanakan terlebih dahulu bagi memastikan segala perancangan dapat dijalankan dengan lancar. Seterusnya, sebarang aktiviti authentic learning perlu mendapat sokongan serta pengesahan melalui surat permohonan rasmi politeknik, surat kebenaran daripada industri dan surat pelepasan kepada pelajar (Elemen 2). Kesemua surat yang dikemukakan ini adalah penting bagi menunjukkan bukti segala aktiviti yang dijalankan adalah secara sah atau rasmi daripada pihak pengurusan. Sebelum ke FASA 2 atau Fasa Perlaksanaan, para pelajar perlu mempunyai gambaran atau view yang jelas berkenaan dengan aktiviti authentic learning yang perlu dijalankan. Oleh itu, terdapat dua elemen penting yang perlu disampaikan kepada pelajar iaitu taklimat daripada pensyarah dan industri kepada pelajar (Elemen 3) berkenaan dengan skop tugasan yang perlu dibuat, serta pemberian rubrik kepada pelajar dan industri (Elemen 4) sebagai panduan untuk mengoptimumkan proses penilaian. Berdasarkan model MPAL, Elemen 3 dan Elemen 4 perlu dilakukan serentak.

FASA 2 pula merupakan Fasa Perlaksanaan. Fasa ini mengandungi tujuh elemen authentic learning. Fasa ini bermula dengan peranan pensyarah yang perlu menyediakan bimbingan kepada pelajar pada masa yang kritikal dan mendorong pelajardengan pelbagaipendekatan (Elemen 11). Jika dilihat dalam model MPAL, elemen ini mempunyai hubungan dengan semua aktiviti yang dijalankan. Justeru, peranan pensyarah bagi menyediakan bimbingan yang sewajarnya amat penting dalam memastikan keberkesanan pendekatan pengajaran 
secara authentic learning. Menurut Herrington, Reeves \& Oliver (2010), dalam persekitaran pembelajaran secara authentic learning, pensyarah yang lebih berpengalaman bertindak sebagai mentor atau fasilitator dan boleh membantu dengan mencetuskan idea untuk menyokong pembelajaran. Pensyarah bukan hanya berperanan untuk memberi syarahan secara pasif, malahan perlu bertindak sebagai fasilitator dan kaunselor dalam membentuk persekitaran pembelajaran yang positif dan membina (Baiba, 2013).

Seterusnya, dua lagi elemen berhubung secara langsung dengan Elemen 11 dalam Fasa Perlaksanaan ini dan perlu dilaksanakan secara serentak. Elemen tersebut adalah semua aktiviti perlu dalam skop yang jelas supaya disiplin ilmu dalam bidang tertentu dapat dipupuk secara bersepadu (Elemen 5) dan semua aktiviti perlu disokong dengan menyediakan sumber yang pelbagai (Elemen 9). Contoh sumber yang pelbagai ini adalah seperti senarai tempat dan pakar yang boleh dirujuk bagi memudahkan pelajar membuat rujukan. Selain itu, tiga lagi elemen perlu dilaksanakan serentak dan berhubung secara terus dengan Elemen 5 dan Elemen 9. Ketiga-tiga elemen tersebut adalah aktiviti yang diberi mampu menghubungkan pengetahuan sedia ada pelajar dengan pengetahuan baru (Elemen 6), aktiviti yang kompleks dipecahkan kepada sub-aktiviti oleh pelajar (Elemen 7) dan aktiviti dapat menggalakkan pelajar berhubung dengan dunia luar di samping dapat menyelesaikan isuisu semasa serta memperkukuhkan pengalaman pelajar (Elemen 8). Bagi memastikan segala aktiviti yang dijalankan bersifat saling melengkapi, elemen terakhir dalam Fasa Perlaksanaan yang menghubungkan elemen-elemen sebelum ini adalah aktiviti perlu dilakukan secara kolaborasi bagi mendapatkan pelbagai perspektif (Elemen 10). Park \& Park (2012) dalam kajian yang bertajuk Development of Professional Engineers' Authentic Contexts in Blended Learning Environments, mendapati elemen kolaborasi merupakan salah satu elemen yang amat penting dalam memastikan kejayaan bagi program pendidikan kejuruteraan. Walaupun kajian mereka memfokuskan kepada keperluan pengajaran secara authentic learning bagi mengatasi kelemahan yang ada dalam aktiviti problem based learning (PBL), namun elemen kolaborasi ini juga merupakan salah satu elemen utama yang sering digunapakai dalam pelbagai pendekatan pengajaran. 
Model MPAL berakhir pada FASA 3 iaitu Fasa Penilaian aktiviti pengajaran. Dalam fasa ini terdapat dua elemen yang perlu dilakukan serentak iaitu menggalakkan refleksi daripada pelajar (Elemen 12) serta penilaian kepada pelajar juga perlu dilakukan secara authentic assessment (Elemen 13). Herrington \& Oliver (2000), menyatakan terdapat tiga kriteria utama dalam penilaian secara authentic assessment. Pertama, pelajar perlu dinilai di sepanjang aktiviti atau tugasan dijalankan, bukan hanya dinilai berdasarkan laporan akhir sahaja. Kedua, pelajar perlu dinilai dengan menggunakan rubrik yang sesuai. Ketiga, pelajar juga perlu dinilai secara individu walaupun aktiviti atau tugasan dilakukan secara berkumpulan yang bertujuan untuk menilai sedikit kelebihan di antara setiap individu terutamanya dari sudut kepimpinan.

\section{KESIMPULAN}

Model MPAL mengandungi 13 elemen authentic learning serta tiga fasa utama telah dibangunkan untuk memberi gambaran dan garis panduan yang jelas berkenaan apakah sebenarnya yang perlu dilakukan oleh para pensyarah untuk menjalankan aktiviti pengajaran secara authentic learning khususnya bagi program kejuruteraan di Politeknik Malaysia. Model-model authentic learning dalam kajiankajian lepas kebanyakannya tertumpu dalam konteks pendidikan di luar negara dan bersifat teoritikal. Model MPAL yang dibangunkan dengan menggunakan aplikasi ISM ini mempunyai kelebihan tersendiri kerana tidak dipersembahkan secara teoritikal tetapi merupakan carta alir aktiviti yang saling berkait. Model MPAL menunjukkan dengan jelas apakah yang perlu dilakukan untuk menjalankan pendekatan pengajaran secara authentic learning secara langkah demi langkah. Justeru, pembangunan model MPAL dengan aplikasi ISM berdasarkan kepada pandangan serta keputusan bersepadu daripada panel pakar yang berkepentingan dalam sistem Politeknik Malaysia memberi keyakinan bahawa model ini boleh digunapakai. 


\section{RUJUKAN}

Akhmal, A. H., Rohana, H., \& Amimudin, U. (2011). Sistem latihan kemahiran dua hala di Malaysia: Satu perbandingan dengan negara Jerman. Journal of Edupres, 1, 214-222.

Andersson, S., \& Andersson, I. (2005). Authentic learning in a sociocultural framework. Scandinavian Journal of Educational Research, 49(4), 419-436.

Baiba, B. (2013). A constructivist approach in engineering education. Paper presented at the 12th Scientific Engineering Cnference for Rural Development, 584-590.

Barab, S. A., Squire, K. D., \& Dueber, W. (2000). A coevolutionary model for supporting the emergence of authenticity. Educational Technology Research \& Development, 48(2), 37-62.

Bennett, S., Agostinho, S., \& Lockyer, L. (2005). Reusable learning designs in university education. In T.C. Montgomerie \& J. R. Parker (Eds.). Proceedings of the IASTED International Conference on Education and Technology. Anaheim, CA: ACTA Press. pp. 102-106.

Betty, P. (2012). Authentic instruction for 21st century learning: higher order thinking in an inclusive school. American Secondary Education, 40(3).

Billett, S. (1996). Accessing and Engaging Vocational Knowledge: Instructional Media versus Everyday Practice. Education Training, Vol. 38, No. 2, pp. 18-25.

Borthwick, F., Bennett, S., Lefoe, G., \& E. Huber. (2007). Applying authentic learning to social science: A learning design for an inter-disciplinary sociology subject. Journal of Learning Design, 2 (1), 14-24.

Delbecq, A. L., Van de Van, A, H., \& Gustafson, D. H. (1975). Group Techniques for program planning. Glenview, IL: Scott, Foresman \& Co.

Ferns, S. (2012). Graduate employability: Teaching staff, employer and graduate perceptions. Proceedings of Australian Collaborative Education Network (ACEN), National Conference Melbourne.

Granton, P., \& Garusetta, E. (2004). Perspectives on authenticity in teaching. Adult Education Quarterly, 55(1), 5-22. 
Hanipah Hussin. (2010). Inovasi jurutera dan pemikiran reflektif. Universiti Teknikal Melaka.

Herrington, J., \& Oliver, R. (2000). An instructional design framework for authentic learning environments. Educational Technology Research and Development, 48(3), 23-48.

Herrington, J., Reeves, T., \& Oliver, R. (2006). authentic tasks online: a synergy among learner, task, and technology. Distance Education, 27(2), 233-247.

Herrington, J., Reeves, T.C \& Oliver, R. (2010). A guide to authentic e-learning. London and New York: Routledge.

Jabatan Pengajian Politeknik. (2013). Laporan Tahunan JPP 2013. Putrajaya: Jabatan Pengajian Politeknik.

Janes, F.R. (1988). Interpretive Structural modelling (ISM): A methodology for structuring complex issue. Trans. Inst. MC. Vol. 10. no.3.

Jonassen, D. H., Strobel, J., \& Lee, C. B. (2006). Everyday problem solving in engineering: lessons for engineering educators. Journal of Engineering Education, 95(2), 1-14.

Kementerian Pengajian Tinggi. (2013). Aspirasi ke arah KPT hebat: fakta ringkas terpilih. Putrajaya: Bahagian Perancangan dan Penyelidikan Kementerian Pengajian Tinggi.

Lombardi, M. M. (2007). Authentic learning for the 21 st century: an overview. ELI Paper1: 2007, EDUCAUSE Learning Initiative.

MLVK. (2005). Implementation of the national dual training system - guides and rules. (2nd ed.). Putrajaya: MLVK.

Murphy, S. H. (2009). Real authentic learning. Principal Leadership, $9(6), 6-8$.

Nicaise, M., Gibney, T., \& Crane, M. (2000).Toward an understanding of authentic learning: student perceptions of an authentic classroom. Journal of Science Education and Technology, 9 ,79-94.

Park, K., \& Park, S. (2012). Development of professional engineers' authentic contexts in blended learning environments. British Journal of Educational Technology, 43(1), 14-18.

Parker, J., Maor, D., \& Herrington, J. (2013). Authentic online learning: aligning learner needs, pedagogy and technology. Issues in Educational Research (Online), 23(2), 227 - 241. 
Reeves, T. C., Herrington, J., \& Olivers, R. (2002). Authentic activities and online learning. Annual Conference Proceedings of Higher Education Research and Development Society of Australasia. Perth, Australia, pp. 562-567.

Revington, S. (2012). Comparing the authentic learning model to other models of education. Dicapai daripada http:// authenticlearning.weebly.com/

Rule, A. (2006). Editorial: The components of authentic learning. Journal of Authentic Learning, 3(1), 1-10.

Sage, A. P. (1977). Interpretive structural modeling: Methodology for large-scale systems. McGraw-Hill, New York, NY.

Stein, S., Isaacs, G., \& Andrews, T. (2004). Incorporating authentic learning experiences within a university course. Studies in Higher Education, 29(2), 239-258.

Von Glasersfeld, E. (1998). Why constructivism must be radical. In M. Larochelle, N. Benarz, \& J. Garrison (Eds.), Constructivism and Education (pp. 23-28). Cambridge: Cambridge University Press.

Wanger, T. (2008). The global achievement gap. New York: Basic Books.

Warfield, J. (1974). Toward interpretation of complex structural Model. IEEE Trans. On System, Man \& Cybernetics, 4 (5), 405-417.

Warfield, J., \& Perino, G.H. (1999).The problematique: Evolution of an idea. System Research and Behavioral Science, 16(3), 221-226.

Webb. (2009). Webb's Depth of knowledge guide: Career and technical education definitions. Dicapai daripada http//www. mde.k12.ms.us pada 15 Januari 2015

Yayasan Kepimpinan Perdana. (2014). Jejak seorang pemimpin: Sejarah lisan Tun Dr Mahathir Mohamad. MPH Group Publishing Sdn. Bhd: Petaling Jaya, Selangor. 